\title{
Antiobesity Potential of Fresh Cow Urine and its Distillate - A Biomedicine for Tomorrow
}

\author{
Sanjay Sharma*, Ketan Hatware, Ashwini Deshpande, Payal Dande, Sravani Karri \\ NMIMS, School of Pharmacy and Technology Management, Shirpur, Maharashtra, INDIA.
}

\begin{abstract}
Background: The cow urine has been used traditionally for the management of many diseases and also used as bio-enhancer to improve their therapeutic effect. Objective: To prepare and evaluate the anti-obesity potential of distillate cow urine and compare with fresh cow urine against high fat diet induced obesity in Wistar rats. Materials and Methods: Qualitative analysis of fresh cow urine and its distillate was done and used for the evaluation of assessment of anti-obesity parameters like BMI, abdominal circumference, obesity index, atherogenic index, lipid profile analysis and histopathological evaluation after two months daily oral treatment against high fat diet induced Obesity. Results: The treated groups with fresh cow urine and its distillate has reduced BMI, abdominal circumference, obesity index, atherogenic index, total cholesterol, triglycerides, LDL-C and VLDL-C Significantly while increased the levels of HDL-C as compared with control group $(P<0.05)$. The Histopathological evaluation revealed the size of visceral white adipose tissue in treated groups was reduced as compared with control Group. Conclusion: In the present research conclude that fresh cow urine and its distillate both are having significant anti-obesity activity against high fat diet induced obesity in Wistar rats.
\end{abstract}

key words: Cow urine, Distillated Cow urine, Anti-obesity, BMI, Atherogenic inde.

\section{INTRODUCTION}

As per World Health Organization (WHO), obesity is a comprehensive hazardous disorder worldwide, with respect to the data analysis of body mass index (BMI). The incidence of obesity increased at a tormenting mark and is the alarming situation for a major public health concern. However, obesity develops metabolic disorders like diabetes mellites, high blood pressure as well as cardiac diseases along with some chronic problems such as sleep apnoea, osteoarthritis, tumour's, stroke in addition to inflammation-based pathologies. ${ }^{1}$ In the present scenario, researchers focused on the therapeutic potential of natural products use for treatment and counteract obesity along with its complications with negligible adverse effects. From past several years various medicines have been using to manage obesity. Though, maximum anti-obesity drugs which were permitted and promoted have now been inhibited due to serious side effects. $^{2}$

From the olden time, Cow's Urine have been using as a remedy. In Ayurveda, Cow's Urine is having its unique role in treatment of various diseases. It's having an immeasurable therapeutic value as well as described in 'Ashtanga Sangraha' and 'Sushruta Samhita' as the utmost useful ingredient/secretion of animal source. It has been known as the water of life or beverages of immortality, the nectar of the God. In India, using of Cow's Urine in drink has been adept for several years. Ayurvedic medicine practitioners regularly use cow's urine as a medicine and the medications prepared from it are used as therapy for numerous illnesses. Perfections have been revealed and described
Submission Date: 17-08-2017; Revision Date: 04-09-2017; Accepted Date: 28-10-2017

DOI: 10.5530/ijper.51.4s.103 Correspondence: Dr. Sanjay Sharma, NMIMS, School of Pharmacy and Technology Management, Shirpur, Maharashtra 425405, INDIA.

Phone no: 9829357499 Email: sanjay.sharma@ nmims.edu

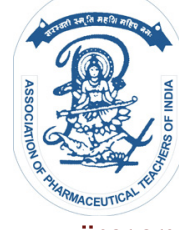

www.ijper.org 
in those suffering from flu, aging, tuberculosis, allergies, leucorrhoea, colds, skin infections, rheumatoid arthritis, chicken pox, bacterial/viral infections, hepatitis, leprosy, ulcer, cardiac disease, asthma, chemical intoxication etc. Cow's Urine can use in many therapy for treatment of numerous treatable and allegedly hopeless illnesses and cow sourced products have multiple roles and benefits. ${ }^{3,4}$ Cow's urine can be used to kill the lots of drugs resistant bacteria as well as virus. As per previous literature the cow's urine has been approved US patent (6896907 and 6410059) for its therapeutic properties, for its use along with antibiotics against bacterial infection along with fights against several types of cancer. ${ }^{5,6}$ nowadays several AIDS patients are attracting towards cow's urine therapy due to its positive outcomes.

The analytical data of Cow's Urine has revealed that it comprises Vitamin A, B, C, D, E, minerals, carbolic acid, chlorine, nitrogen, manganese, creatinine, hormones, magnesium, sulphur, iron, tartaric acid, phosphate, sodium, silicon, citric acid, succinic acid, calcium salts, lactose, enzymes, and gold. In deficiency or excess of these constituents inside the body can make an ill to the individual. Cow's urine comprises these substances that are naturally existing in the human body. Thus, ingesting of cow's urine sustains the equilibrium of these substances and this supports to cure incurable illnesses., 8 Based on extensive literature survey and patent search state that there is no scientific data explored on the antiobesity activity of cow's urine and its distillate, hence, the study delineated with the anti-obesity property of cow's urine and its distillate in experimentally induced obesity in Wistar rats.

\section{MATERIALS AND METHODS}

\section{Animals}

Young Wistar rats of either sex, weighing approximately $120-150 \mathrm{~g}$ was housed in room temperature of $25 \pm 1^{\circ} \mathrm{C}$ and $12 \mathrm{~h}$ light and dark cycles. Animals were fed on a standard chow diet (Nutrivet Life sciences, Pune, India) and water ad libitum. The experimental protocol was approved by the Institutional Animal Ethics Committee (IAEC) and carried out according to the guidelines given by Committee for Control and Supervision of Experiments on Animals (CPCSEA), New Delhi, India CPCSEA Approval No.: SPTM-IAEC/2016-2017/01/11, (Registration No: 1300/ac/09/CPCSEA).

\section{Drugs and Chemicals}

Diagnostic kits for Total cholesterol, HDL, Triglycerides purchased from Jinendra scientific, Jalgaon, Maharashtra, India and Lova Chemicals, Mumbai, Maharashtra, India.

\section{Collection of FCU}

FCU was collected personally from Maa Kanakeshwari Goshala, Bombay-Agra Road, and Shirpur-425 405.

\section{Preparation of $\mathrm{DCU}$}

DCU was prepared by the simple distillation process. FCU was boiled in a round bottom flask to which a vapor condensing device was attached. The vapors through tube were collected in a pot put over cold water. The DCU was kept in a closed amber colored container and stored in cool place.

\section{Elemental analysis of FCU and DCU 9 \\ Preparation of Lassaigne's Solution (Sodium Filtrate)}

Introduced a freshly cut, clean and dry piece of sodium metal into an ignition tube, which was held in vertical position with a pair of the thong. The lower part of the tube was heated gently till sodium melted to a shining globule. Removed the ignition tube from the flame and added a small amount of FCU. Heated the tube on the flame till the reaction ceased and the tube became red hot. Now plunged the tube into about $20 \mathrm{ml}$ of distilled water in a china dish and broken the bottom of the tube by striking against the dish. The contents were heated to boiling for the few min. It was then cooled and filtered to get a colorless alkaline filtrate (Lassaigne's solution). This solution was also prepared for DCU.

\section{Test for nitrogen in FCU and DCU}

The Lassaigne's solution $(2 \mathrm{ml})$ was taken in a test tube and added some drops of freshly prepared aqueous ferrous sulfate solution. Formation of the dark green color of ferrous hydroxide was formed indicated the presence of nitrogen. The mixture was heated to boiling, cooled and acidified with Sulphuric acid. Formation of Prussian blue color shows the existence of nitrogen.

\section{Test for sulfur in FCU and DCU}

The Lassaigne's solution $(2 \mathrm{ml})$ added 2-3 drops of freshly prepared sodium nitroprusside solution. The violet colour indicates the presence of sulfur.

\section{Test for chloride in FCU and DCU}

The Lassaigne's solution was acidified with dilute nitric acid and added a few drops of silver nitrate solution, the formation of white precipitate indicates the presence of nitrogen.

\section{Qualitative Examination of Inorganic and Organic Matters in FCU and DCU $10,11,12$}

It involved qualitative examinations of inorganic (those, which are free from carbon) and organic matters (may be secondary metabolites products in the cow's urine). The role of these components for the medicinal 
purpose is important, hence detected by simple chemical analysis. The test methods of main components are as given in Table 1.

\section{Determination of $\mathrm{pH}$ and Specific Gravity of FCU and $D C U^{13,14}$}

\section{The procedure of $\mathrm{pH}$ Determination}

The glass electrode was washed with distilled water gently before the operation and calibrated with standard solutions of different $\mathrm{pH}(4,7$ and 9) and the $\mathrm{pH}$ of samples of FCU and DCU were recorded.

\section{The procedure of Specific Gravity Determination}

The weighing bottle was weighed and then a fixed amount of sample of FCU and DCU were filled in weighing bottle and weighed again. After this, the empty bottle was again weighed and then the specific gravity was calculated.

\section{Acute toxicity studies (as per OECD guidelines) ${ }^{15}$}

The study was carried out as per OECD guidelines and received draft 423 guidelines from the committee CPCSEA, Government of India.

\section{High-Fat Diet Formula (HFD) ${ }^{16}$}

It consists of fat $58 \%$, protein $25 \%$ and carbohydrate $17 \%$, lard $13 \%$, cholesterol $1 \%$, vitamin, and minerals $0.6 \%$ as a percentage of total $\mathrm{kcal}$ ad libitum, the animals selected for the study were fed with this composition for a period of two months.

\section{Pharmacological assessment}

Experimental design

After one week of acclimatization, the animals were separated into six groups each containing six animals,

Group I: Received only normal diet without any treatment.

Group II: Received HFD without any treatment.

Group III: Received HFD and daily treatment of $1 \mathrm{ml} / \mathrm{kg}$ of body weight with FCU.

Group IV: Received HFD and daily treatment of $2 \mathrm{ml} / \mathrm{kg}$ of body weight with FCU.

Group V: Received HFD and daily treatment of $1 \mathrm{ml} / \mathrm{kg}$ of body weight with DCU.

Group VI: Received HFD and daily treatment of $2 \mathrm{ml} / \mathrm{kg}$ of body weight with DCU.

The various parameters like BMI, AC, OI, TC, TG, HDL-C, LDL-C, VLDL-C and AI were evaluated at the starting and after completion of 2 months' treatment of FCU and DCU according to the groups mentioned above.

\section{Morphological Parameters to measure obesity}

Evaluation of BMI, Abdominal Circumference and Obesity index ${ }^{17,18}$

The BMI, AC and Obesity index are the major parameters to be evaluated in the assessment of anti-obesity drug. In the present study, BMI was evaluated by following formula

BMI = body weight $(\mathrm{g}) /$ length ${ }^{2}\left(\mathrm{~cm}^{2}\right)$

Abdominal circumference was measured using a measuring tape. The obesity index was determined by formula, Obesity index $=$ Cube root of body weight of rat (g)/ nasoanal length $(\mathrm{mm}) \times 10^{4}$

\section{Evaluation of Lipid Profile}

On the $1^{\text {st }}$ day and $60^{\text {th }}$ day of the experiment, the blood samples were withdrawn from retro-orbital plexus of all the animals into sterilized dry Eppendorf tubes then allowed to stand for 30 to $40 \mathrm{~min}$ at room temperature. The clear serum was separated at $3000 \mathrm{rpm}$ for $15 \mathrm{~min}$ by centrifugation. The levels of serum TC, HDL-C, TG were determined using semi-auto analyser (Erba), according to the procedure given in respective diagnostic kits. To calculate serum LDL-C and VLDL-C values Friedewald formula was used.

LDL-C $=$ TC-(HDL-C +TG $/ 5)$

VLDL-C $=\mathrm{TG} / 5$

Atherogenic index (AI). ${ }^{19,20}$

The AI was calculated by the following formula.

$\mathrm{AI}=($ Total cholesterol - HDL-C) $/$ HDL-C

\section{Histopathological evaluation}

At the termination of the experimental period, rats were sacrificed by spinal dislocation. The white adipose tissues were fixed in 10\% formalin solution and embedded in paraffin were subjected to histopathological evaluation. Standard sections of $5 \mu \mathrm{m}$ thickness were cut, stained using hematoxylin and eosin and examined under an optical microscope (40X).

\section{Statistical Analysis}

All outcomes are expressed as the mean \pm SEM. The results were evaluated for statistical significance using ANOVA and Dunnett's test. P values $<0.05$ were measured as significant (Using prism software 5.2 version).

\section{RESULTS}

\section{Elemental analysis of FCU and DCU}

The elemental analysis was performed as per the procedures mentioned in above section of materials and methods and the results are expressed in Table 2.

\section{Qualitative analysis of FCU and DCU}


Table 1: Qualitative test for chemical composition of FCU and DCU

\begin{tabular}{|c|c|c|}
\hline COMPONENT & TEST & OBSERVATION \\
\hline Urea & $\begin{array}{c}\text { (UREASE TEST) } \\
\text { Sample and added Soya bean meal with Phenol red }\end{array}$ & Formation of red color indicate presence of urea. \\
\hline Potassium & $\begin{array}{c}3 \mathrm{ml} \text { sample and added few drops of sodium cobalt nitrite } \\
\text { solutions }\end{array}$ & $\begin{array}{c}\text { Formation of yellow precipitate indicate presence of } \\
\text { potassium. }\end{array}$ \\
\hline Calcium & Sample and added Amino oxalate & $\begin{array}{c}\text { Formation of white precipitate indicate presence of } \\
\text { calcium. }\end{array}$ \\
\hline Iron & $\begin{array}{c}5 \mathrm{ml} \text { of test solution and added few drops of } 2 \% \\
\text { potassium Ferro cyanide }\end{array}$ & $\begin{array}{c}\text { Formation of dark blue coloration indicate presence } \\
\text { of iron }\end{array}$ \\
\hline Phosphorus & Sample and added Conc. Nitric acid & $\begin{array}{l}\text { Formation of white precipitate indicate presence of } \\
\text { phosphorus. }\end{array}$ \\
\hline Bi-carbonate & $3 \mathrm{ml}$ of urine and added dilute $\mathrm{HCL}$ & $\begin{array}{l}\text { Effervescence produce which confirms presence of } \\
\text { bi-carbonates }\end{array}$ \\
\hline Sulphate & Sample and added $\mathrm{Bacl}_{2}$ & $\begin{array}{l}\text { Formation of white precipitate indicate presence of } \\
\text { sulphate }\end{array}$ \\
\hline Bile pigment & $\begin{array}{c}\text { (PETEN KOFERS TEST) } \\
5 \mathrm{ml} \text { of sample and added Dissolved crystal of sucrose, } \\
\text { added } 3 \mathrm{ml} \text { of conc. Sulphuric acid }\end{array}$ & $\begin{array}{c}\text { Formation of reddish purple ring indicate presence of } \\
\text { bile pigment. }\end{array}$ \\
\hline Carbohydrate & $\begin{array}{c}\text { (MOLISH TEST) } \\
\text { Sample and added } \begin{array}{c}\text { molish reagent ,added conc. sulpuric } \\
\text { acid }\end{array}\end{array}$ & $\begin{array}{l}\text { Formation of violet ring formed at the junction } \\
\text { indicate presence carbohydrate. }\end{array}$ \\
\hline Protein & $\begin{array}{c}\text { (HELLER'S TEST) } \\
3 \mathrm{ml} \text { of sample and added } 3 \mathrm{ml} \text { conc. Nitric acid }\end{array}$ & $\begin{array}{l}\text { Formation of white precipitate formed at the junction } \\
\text { indicate presence of protein. }\end{array}$ \\
\hline Ketone bodies & $\begin{array}{l}\text { (ROTHER's TEST) } 5 \mathrm{ml} \text { of sample, added Saturated } \\
\text { with solid ammonium sulphate and added } 2-3 \mathrm{drop} \text { of } \\
5 \% \text { solution of sodium nitroprusside, added } 2 \mathrm{ml} \text { conc. } \\
\text { Ammonia }\end{array}$ & $\begin{array}{l}\text { No permanent colour was formed which indicate } \\
\text { presence of ketene bodies. }\end{array}$ \\
\hline Creatinine & $\begin{array}{c}\text { (JAFFE'S TEST) } \\
5 \mathrm{ml} \text { of sample and added } 2 \mathrm{ml} \text { saturated picric acid with } \\
10 \% \mathrm{NaOH}\end{array}$ & $\begin{array}{c}\text { Formation of Deep orange colour indicate presence } \\
\text { of creatinine }\end{array}$ \\
\hline Ammonia & Take $5 \mathrm{ml}$ of FCU or DCU added on red litmus paper & $\begin{array}{l}\text { Litmus paper turned to blue indicate presence of } \\
\text { ammonia. }\end{array}$ \\
\hline Uric acid & $\begin{array}{l}\text { (SCHIFF'S TEST) } \\
\text { Moisten a strip of filter paper with Silver nitrate solution } \\
\text { and added to it a drop of urine }\end{array}$ & $\begin{array}{c}\text { Formation of black or yellow brown strain indicate } \\
\text { presence of uric acid. }\end{array}$ \\
\hline Tartaric acid & $\begin{array}{l}\text { 2-3 } \mathrm{ml} \text { Of test solution ,added one drop dilute } \mathrm{NH}_{4} \mathrm{OH} \text { and } \\
\text { excess } 5 \% \mathrm{AgNO}_{3} \text { solution ,boiled for } 15 \mathrm{~min} \text {. on water } \\
\text { bath }\end{array}$ & $\begin{array}{c}\text { Formation of white gelatinous precipitate indicate } \\
\text { presence of tartaric acid. }\end{array}$ \\
\hline Oxalic acid & $2 \mathrm{ml}$ sample and added few drops $5 \%$ lead acetate & $\begin{array}{l}\text { Formation of white precipitate indicate presence of } \\
\text { oxalic acid. }\end{array}$ \\
\hline
\end{tabular}

\begin{tabular}{|c|c|c|c|}
\hline \multicolumn{2}{|c|}{ Table 2 : Results of element detection tests for FCU and DCU } \\
\hline \multirow{3}{*}{ Preparations } & Test for elements & Observation & Inference \\
\hline \multirow{3}{*}{ FCU } & Nitrogenurine(Ganvati)ion & Blue color & $(+)$ \\
\cline { 2 - 4 } & Sulphur & violet color & $(+)$ \\
\cline { 2 - 4 } & Chloride & White precipitate & $(+)$ \\
\hline \multirow{3}{*}{ DCU } & Nitrogenurine(Ganvati)ion & Blue color & $(+)$ \\
\cline { 2 - 4 } & Sulphur & violet color & $(+)$ \\
\cline { 2 - 4 } & Chloride & No White precipitate & $(-)$ \\
\hline
\end{tabular}




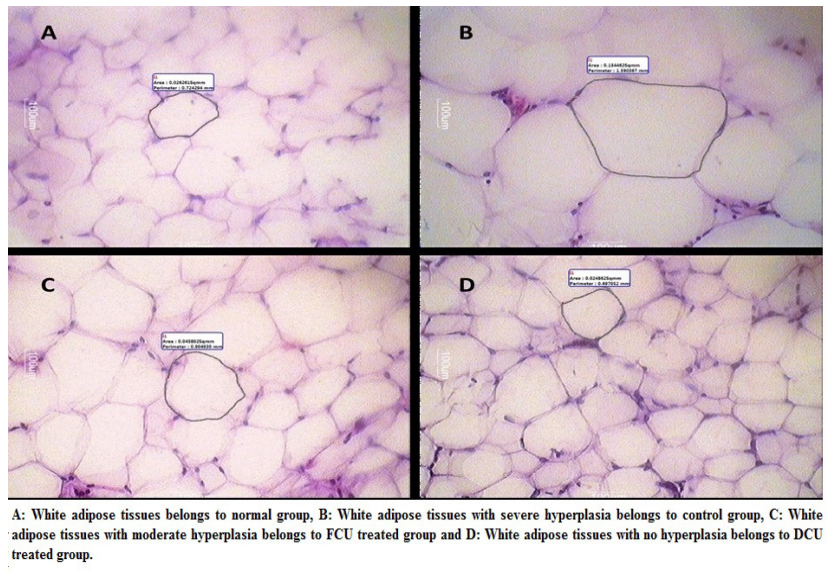

Figure 1: Histological evaluation of white adipose tissues.

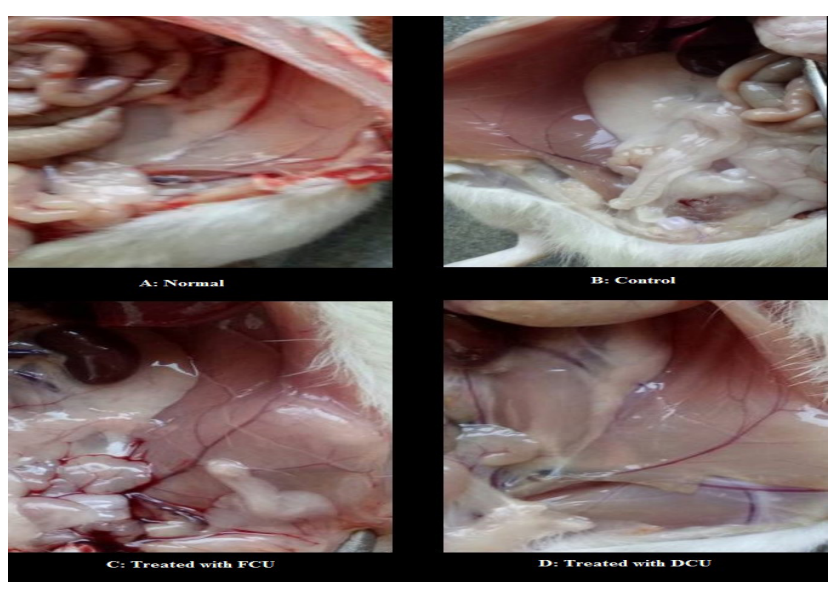

Figure 2: White Adipose Tissue Accumulation.

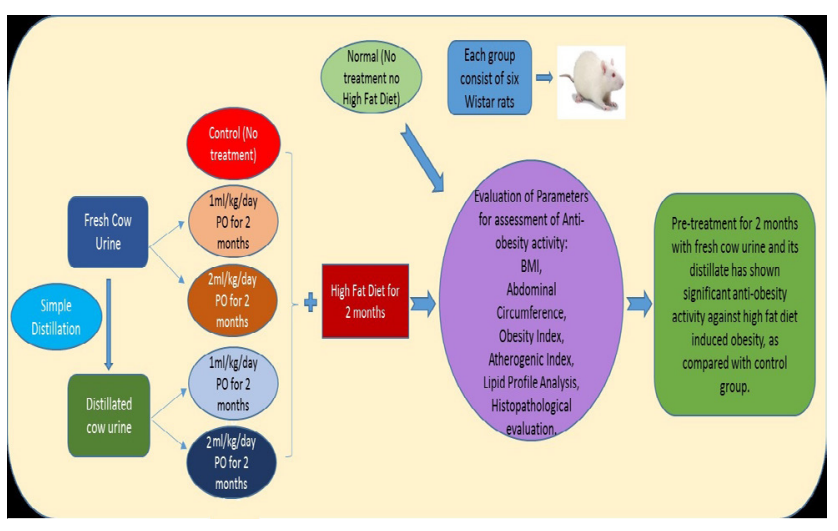

Figure 3: Graphical Summary.

The qualitative analysis of the FCU and DCU was performed as per the procedures mentioned in the above section of materials and methods Table 1 and results are expressed in Table 3.

Determination of $\mathrm{pH}$ and Specific Gravity of FCU and
Table 3: Results of qualitative examination of inorganic and organic matters in FCU and DCU

\begin{tabular}{|c|c|c|}
\hline Components & FCU & DCU \\
\hline Urea & $(+)$ & $(-)$ \\
\hline Potassium & $(+)$ & $(+)$ \\
\hline Calcium & $(+)$ & $(-)$ \\
\hline Iron & $(+)$ & $(-)$ \\
\hline Phosphorus & $(-)$ & $(-)$ \\
\hline Bi-carbonate & $(+)$ & $(+)$ \\
\hline Sulphate & $(+)$ & $(-)$ \\
\hline Bile pigment & $(+)$ & $(-)$ \\
\hline Carbohydrate & $(-)$ & $(+)$ \\
\hline Protein & $(-)$ & $(-)$ \\
\hline Ketone bodies & $(-)$ & $(-)$ \\
\hline Creatinine & $(+)$ & $(-)$ \\
\hline Ammonia & $(+)$ & $(+)$ \\
\hline Uric acid & $(+)$ & $(+)$ \\
\hline Tartaric acid & $(+)$ & $(+)$ \\
\hline Oxalic acid & $(+)$ & $(+)$ \\
\hline
\end{tabular}

According the tabulated data (Table III), bi-carbonate,.ammonia, uric acid, potassium, oxalic acid, and were commonly present in FCU and DCU.

Table 4: $\mathrm{PH}^{\mathrm{H}}$ and Specific gravity of FCU and DCU

\begin{tabular}{|c|c|c|}
\hline preparations & $\mathrm{PH}^{\mathrm{H}}$ & Specific gravity \\
\hline FCU & $7.82 \pm 0.05$ & $1.027 \pm 0.13$ \\
\hline DCU & $8.82 \pm 0.07$ & $0.997 \pm 0.08$ \\
\hline
\end{tabular}

(Data represents Mean of triplicate \pm s.d) According the tabulated data the $\mathrm{pH}$ of FCU and DCU were found to be alkaline.

\section{$D C U$}

The $\mathrm{pH}$ and specific gravity of FCU and DCU were determined and expressed in the Table 4.

\section{Acute Toxicity Study}

The acute toxicity study was done as per OECD guidelines (423). The FCU and DCU were administered orally to test animals at different doses maximum up to $10 \mathrm{ml} / \mathrm{kg}$ and observed for $24 \mathrm{~h}$ and no mortality, abnormal sign and symptoms were seen for one week.

Evaluation of BMI, Abdominal Circumference, and Obesity index before the treatment (initial)

The BMI, abdominal circumference and obesity index were evaluated before starting the treatment on the initial day. All the values of these parameters of normal and treated groups were statistically insignificant as compared with the control group, except BMI and obesity index of the treated group. However, the values of con- 
Table 5: Evaluation of BMI, Abdominal Circumference and Obesity index ( $1^{\text {st }}$ day)

\begin{tabular}{|c|c|c|c|}
\hline Groups & BMI & AC & OI \\
\hline I Normal & $0.66 \pm 0.0169$ & $12.58 \pm 0.352$ & $0.033 \pm 0.00037$ \\
\hline II Control & $0.63 \pm 0.0115$ & $13.25 \pm 0.214$ & $0.033 \pm 0.000239$ \\
\hline III FCU(1 ml/kg) & $0.66 \pm 0.0193$ & $12.75 \pm 0.214$ & $0.034 \pm 0.000405^{* *}$ \\
\hline IV FCU(2 ml/kg) & $0.69 \pm 0.0094^{* *}$ & $12.83 \pm 0.307$ & $0.034 \pm 0.000301^{* *}$ \\
\hline V DCU(1 ml/kg) & $0.68 \pm 0.0081^{* *}$ & $12.33 \pm 0.357$ & $0.035 \pm 0.000272^{* *}$ \\
\hline VI DCU(2 $\mathbf{~ m l / k g ) ~}$ & $0.71 \pm 0.0102^{* *}$ & $12.75 \pm 0.281$ & $0.035 \pm 0.000272^{* *}$ \\
\hline
\end{tabular}

** $p<0.05$ (significant) when compared the other group with control group by using ANOVA followed by Dunnett's test. ( $N=6$ values Mean \pm SEM)

\begin{tabular}{|c|c|c|c|c|c|c|}
\hline Groups & Total CH & TG & HDL & VLDL & LDL & Al \\
\hline I Normal & $77.62 \pm 2.44$ & $75.51 \pm 4.14$ & $48.04 \pm 2$ & $15.10 \pm 0.827$ & $14.47 \pm 3.09$ & $0.62 \pm 0.0686$ \\
\hline II Control & $75.36 \pm 4.43$ & $73.73 \pm 5.56$ & $44.07 \pm 3.15$ & $14.74 \pm 1.11$ & $16.54 \pm 1.91$ & $0.71 \pm 0.0376$ \\
\hline $\begin{array}{l}\text { III FCU } \\
(1 \mathrm{ml} / \mathrm{kg})\end{array}$ & $77.83 \pm 4.83$ & $71.10 \pm 2.94$ & $49.42 \pm 3.43$ & $14.22 \pm 0.588$ & $14.18 \pm 2.24$ & $0.58 \pm 0.055$ \\
\hline $\begin{array}{l}\text { IV FCU } \\
(2 \mathrm{ml} / \mathrm{kg})\end{array}$ & $72.42 \pm 2.78$ & $87.69 \pm 4.24$ & $40.05 \pm 2.71$ & $17.53 \pm 0.848$ & $14.83 \pm 1$ & $0.82 \pm 0.0655$ \\
\hline $\begin{array}{l}\text { V DCU } \\
(1 \mathrm{ml} / \mathrm{kg})\end{array}$ & $76.20 \pm 2.46$ & $82.42 \pm 3.83$ & $43.35 \pm 2.4$ & $16.48 \pm 0.765$ & $16.36 \pm 2.44$ & $0.77 \pm 0.0842$ \\
\hline $\begin{array}{l}\text { VI DCU } \\
(2 \mathrm{ml} / \mathrm{kg})\end{array}$ & $77.10 \pm 3.42$ & $83.25 \pm 2.54$ & $43.94 \pm 3.99$ & $16.65 \pm 0.507$ & $16.51 \pm 1.43$ & $0.79 \pm 0.1$ \\
\hline
\end{tabular}

$\mathrm{p}>0.05$ (Not significant) when compared the other group with control group by using ANOVA followed by Dunnett's test. (N=6 values Mean \pm SEM) on $1^{\text {st }}$ day.

trol groups were less and values of treated groups were high, it was indicating that the BMI and obesity index of the control group were smaller than other treated groups. Results are given in Table 5.

\section{Evaluation of Lipid Profile and Atherogenic index (Al) before the treatment (initial)}

The serum lipid profile (TC, TG, HDL-C, LDL-C, and VLDL-C) and atherogenic index were evaluated before starting the treatment on the initial day. All the values of these parameters of normal and treated groups were statistically insignificant as compared with the control group. Results are given in Table 6.

\section{Evaluation of BMI, Abdominal Circumference, and Obesity index after two months treatment}

The BMI, abdominal circumference and obesity index were evaluated after two months' treatment on the $60^{\text {th }}$ day. The results of this study revealed that BMI, abdominal circumference, and obesity index of the control group were increased to a maximum level at the same time treatment of FCU and DCU decreased the values of same parameters significantly, except obesity index of the group treated with low dose of FCU. Results are given in Table 7.

Evaluation of Lipid Profile and Atherogenic index (Al) after two months

The serum lipid profile (TC, TG, HDL-C, LDL-C, and VLDL-C) and atherogenic index were evaluated after two months' treatment on the $60^{\text {th }}$ day. All the values of these parameters of normal and treated groups were statistically significant as compared with the control group. Results are given in Table 8.

\section{Histopathological Evaluation}

Histological examinations of this study have been revealed that the sizes of the white adipocytes were significantly reduced in FCU and DCU treated groups when compared with control group Figure 1. However, the effect of the DCU treated group is greater than FCU treated group.

\section{DISCUSSION}

As in view of the inadequate accessibility of drugs having anti-obesity effect and considering their adverse effects, 
Table 7: Evaluation of BMI, Abdominal Circumference and Obesity index (60 ${ }^{\text {th }}$ day)

\begin{tabular}{|c|c|c|c|}
\hline Groups & BMI & AC & OI \\
\hline I Normal & $0.63 \pm 0.0169$ & $14.58 \pm 0.239$ & $0.030 \pm 0.000270$ \\
\hline II Control & $0.80 \pm 0.0263$ & $20.08 \pm 0.507$ & $0.033 \pm 0.000322$ \\
\hline III FCU(1 ml/kg) & $0.67 \pm 0.0349^{* *}$ & $13.41 \pm 0.436^{* *}$ & $0.032 \pm 0.000624$ \\
\hline IV FCU(2 ml/kg) & $0.54 \pm 0.0269^{* *}$ & $13.33 \pm 0.211^{* *}$ & $0.030 \pm 0.000583^{* *}$ \\
\hline V DCU(1 ml/kg) & $0.58 \pm 0.0112^{* *}$ & $14.08 \pm 0.300^{* *}$ & $0.030 \pm 0.000194^{* *}$ \\
\hline VI DCU(2 ml/kg) & $0.48 \pm 0.0234^{* *}$ & $13.33 \pm 0.279^{* *}$ & $0.028 \pm 0.000478^{* *}$ \\
\hline
\end{tabular}

** $\mathrm{p}<0.05$ (significant) when compared the other group with control group by using ANOVA followed by Dunnett's test. ( $N=6$ values Mean $\pm \mathrm{SEM}$ )

\begin{tabular}{|c|c|c|c|c|c|c|}
\hline Groups & Total $\mathrm{CH}$ & TG & HDL & VLDL & LDL & Al \\
\hline I Normal & $81.50 \pm 1.77$ & $81.58 \pm 4.96$ & $51.59 \pm 2.5$ & $16.31 \pm 0.992$ & $13.60 \pm 2.14$ & $0.59 \pm 0.0637$ \\
\hline II Control & $131.42 \pm 4.37$ & $166.21 \pm 14.5$ & $32.43 \pm 3.61$ & $33.24 \pm 2.89$ & $65.74 \pm 2.14$ & $3.34 \pm 0.526$ \\
\hline $\begin{array}{l}\text { III FCU } \\
\text { (1 ml/kg) }\end{array}$ & $107.42 \pm 4.06^{* *}$ & $125.25 \pm 5.37^{* *}$ & $51.33 \pm 3.34^{* *}$ & $25.05 \pm 1.07^{* *}$ & $31.03 \pm 3.87^{* *}$ & $1.13 \pm 0.166^{* *}$ \\
\hline $\begin{array}{l}\text { IV FCU } \\
\text { (2 } \mathrm{ml} / \mathrm{kg})\end{array}$ & $91.46 \pm 4.06^{* *}$ & $108.45 \pm 4.39^{* *}$ & $54.71 \pm 1.81^{* *}$ & $21.69 \pm 0.878^{* *}$ & $15.06 \pm 4.65^{* *}$ & $0.68 \pm 0.0997^{* *}$ \\
\hline $\begin{array}{l}\text { V DCU } \\
(1 \mathrm{ml} / \mathrm{kg})\end{array}$ & $105.98 \pm 3.66^{* *}$ & $118.57 \pm 2.97^{* *}$ & $48.25 \pm 2.82^{* *}$ & $23.71 \pm 0.594^{* *}$ & $34.01 \pm 4.37^{* *}$ & $1.23 \pm 0.141^{* *}$ \\
\hline $\begin{array}{l}\text { VI DCU } \\
(2 \mathrm{ml} / \mathrm{kg})\end{array}$ & $87.85 \pm 1.99^{* *}$ & $97.18 \pm 4.92^{* *}$ & $55.55 \pm 1.82^{* *}$ & $19.43 \pm 0.984^{* *}$ & $12.86 \pm 1.4^{* *}$ & $0.58 \pm 0.0322$ \\
\hline
\end{tabular}

** $p<0.05$ (significant) when compared the other group with control group by using ANOVA followed by Dunnett's test. ( $N=6$ values Mean \pm SEM)

the search remains to discovery active natural product based medicines to fight against obesity. The occurrence of obesity is rapidly rising and the consequences are directly or indirectly leads to the serious and lifethreatening metabolic disorders. It has been reported that rats fed a diet containing high fat resulted in distinctive visceral adiposity, dyslipidemia and oxidative stress which are typically associated with obesity. ${ }^{21,22}$ The HFD induced obesity is known to be the most significant model for the assessment of anti-obesity activity because of its close resemblance of copycatting the usual route of obesity episodes in human beings. ${ }^{23,24}$ Thus, in the present study high-fat diet was given for 2 months to the Wistar rats for induction of obesity to develop the experimental model to be utilized for the assessment of anti-obesity activity. It is well established that over-consumption food along with the high concentration of fat lead to obesity in several animal's models including rats due to metabolic complications as well as liver dysfunction. It was well documented in many studies that obesity is also related with a dyslipidemia with an increase in the levels of TG, LDL-C, VLDL-c and decrease in the levels of HDL-C. ${ }^{25,26,27}$ The results and observations of this research showed that rats exposed to a diet containing high fat for 2 months increased the body weight significantly, thus it was confirmed the obese status of the rats fed with HFD. ${ }^{28}$ The difference in the body weight was observed between the groups fed a HFD and normal diet, however, no substantial difference was detected in the daily food intake of animals. This observation revealed the fact that an increase in body weight was not dependent on the extent of food consumed by the rats but it was a result of consumption of HFD.As stated earlier high-fat diet resulted in lipid abnormalities associated to obesity include an raised serum concentration of fatty acids, TC, LDL-C, VLDL-C, TG and reduction in serum HDL-C. ${ }^{29,30}$ results of the evaluation of lipid profile from control group of this study revealed similar observations thus here confirmed the establishment of the experimental model for the assessment of anti-obesity activity. This suggest that the fresh cow urine and its distillate may reduce pancreatic lipase activity thus reducing the absorption of dietary fat and regulates lipid profile. In epidemiological studies, BMI is widely considered as a prominent marker for assessment of obesity hence evaluation of the BMI 
was done. There was a significant reduction in BMI, $\mathrm{AC}$ and OI of FCU and DCU treated groups were observed as compared to the control group. In addition to its weight reducing the effect, FCU and DCU treated HFD rats showed significantly lowered levels of serum TC, TG, LDL-C, VLDL-C and increased levels of HDL-C. It is stated that obesity, particularly abdominal obesity, is related with dyslipidemia, characterized by raised TG and decreased HDL-C concentrations. ${ }^{31}$ TGs are involved in the ectopic gathering of lipid stores in the hepatic part and are linked with a various disorder like metabolic syndrome. VLDL-C carriages cholesterol and TG to the tissues, whereas HDL-C is supportive in carrying extra cholesterol to the liver for elimination in the bile. ${ }^{32}$ Elevated level of TC and LDL-C in addition to low level of HDL-C are risk factors for coronary artery disease $(\mathrm{CAD})^{33}$ Therefore, the atherogenic index was assessed and it was expressively decreased in FCU and DCU treated groups as compared to control group. Extreme growing of adipose tissue results in obesity that includes hyperplasia and hypertrophy. ${ }^{34}$ Decrease in body weight gain of HFD-fed rats was escorted by a reduction of body fat stores since treatment with FCU and DCU also expressively decreased the weight and deposition of adipose tissues as compared with that control group. These data confirmed that FCU and DCU have an inhibitory effect on hypertrophy and hyperplasia of white adipose tissue. Results of histopathological evaluation shown in Figure 1, revealed that white adipose tissues size were increased in control group whereas decreased in groups treated with FCU and DCU and it was like the normal group. Therefore, FCU and DCU both are reducing the deposition of white adipose tissues and prevents obesity against high-fat diet. The outcomes of the current study supporting the lipid-lowering activity of DCU shown in guinea pig. ${ }^{35}$

\section{CONCLUSION}

As per the results of the current research work, it has been determined that the treatment of FCU and DCU at doses $1.0 \mathrm{ml} / \mathrm{kg}$ and $2 \mathrm{ml} / \mathrm{kg}$ shown significant anti-obesity in HFD-induced obese rats. Further, research is required to be done to determine the different fraction and active principles and components of the FCU and DCU, followed by the establishment of a molecular mechanism of action for anti -obesity potential. Present research highlights the anti-obesity potential of fresh cow urine and Distillated cow urine, the strategies for the profit of mankind with the understanding that cow urine therapy desires instant attention, advancement, and extensive acceptance and appropriate support of the expert, scientists and clinicians to support alternative low-cost therapy having no or insignificant adverse effect.

\section{ACKNOWLEDGEMENT}

We would like to thank NMIMS, School of Pharmacy and Technology Management for providing Animal house facilities and also thankful to Maa Kanakeshwari Goshala, Bombay-Agra Road, Shirpur for providing fresh cow urine.

\section{CONFLICT OF INTEREST}

There is no conflict of interest.

\section{ABBREVIATIONS USED}

FCU: Fresh Cow Urine, DCU: Distilled Cow Urine, HFD: High-Fat Diet, BMI: Body Mass Index, AI: Atherogenic Index, AC: Abdominal Circumference, OI: Obesity Index, TC: Total Cholesterol, TG: Triglycerides, LDL-C: Low-Density Lipoprotein, VLDL-C: Very Low-Density Lipoprotein, HDL-C: High-Density Lipoprotein, CPCSEA: Committee for the Purpose of Control and Supervision of Experiments on Animals, OECD: Organisation for Economic Co-operation and Development.

\section{REFERENCES}

1. Ham, JR., Lee, HI., Choi, RY., Sim, MO., Seo, KI., et al. Anti-steatotic and anti-inflammatory roles of syringic acid in high-fat diet-induced obese mice. Food and function, 2016, 7(2), 689-697.

2. Kang, JG and Park, CY. Anti-obesity drugs: a review about their effects and safety. Diabetes and metabolism journal,2012, 36(1), 13-25.

3. Hirapara, HN. Ghori, VM. Anovadiya, AP., and Tripathi, CR. Evaluation of wound healing activity of cow urine ark in diabetic Wistar albino rats. Journal of intercultural ethnopharmacology,2016, 5(4), 434.

4. Sajid, M., Khan, M. R., Shah, NA., Shah, SA., Ismail, H., Younis, T., and Zahra, Z. Phytochemical, antioxidant and hepatoprotective effects of Alnus nitida bark in carbon tetrachloride challenged Sprague Dawley rats. BMC complementary and alternative medicine,2016, 16(1), 268.

5. Randhawa, G. Cow urine distillate as bioenhancer. Journal of Ayurveda and integrative medicine, 2010, 1(4), 240.

6. Randhawa, G. K., and Sharma, R. Chemotherapeutic potential of cow urine: A review. Journal of intercultural ethnopharmacology, 2015, 4(2), 180.

7. Pitchaiah, G., Akula, A., and Chandi, V. Anticancer potential of nutraceutical formulations in MNU-induced mammary cancer in Sprague Dawley rats. Pharmacognosy magazine, 2017, 13(49), 46.

8. Smith, G. D. Cow urine, Indian yellow, and art forgeries: An update. Forensic Science International, (2017).

9. Adams, R., and Johnson, J. R. Elementary laboratory experiments in organic chemistry. Journal of Chemical Education (1935) 5(12), 1708.

10. Day, J. E. Practical Chemistry with Experiments. Revised edition (Newell, Lyman C.), Journal of Chemical Education, (1930), 7(3) (1930) 724.

11. Gordin, HM. PRACTICAL TEST-BOOK OF CHEMISTRY. Journal of the American Chemical Society, (1907), 29(11), 1637-1637. 
12. Helmkamp RW., A Text-book of Practical Organic Chemistry Including Qualitative Organic Analysis. Journal of the American Chemical Society. 1956 Nov; 78 (21):5707.

13. Robyt JF, White BJ, Laboratory practical exams in the biochemistry lab course. J. Chem. Educ. 1990 Jul 1; 67(7):600.

14. Schales O. Practical clinical biochemistry (Varley, Harold), Journal of Chemical Education 40(10) (1963) A834.

15. Sharwan G, Jain P, Pandey R, Shukla SS. Toxicity and Safety Profiles of Methanolic Extract of Pistacia integerrima JL Stewart ex Brandis (PI) for Wistar Rats. Journal of pharmacopuncture. 2016 Sep;19(3):253.

16. Bais S, Singh GS, Sharma R. Antiobesity and hypolipidemic activity of Moringa oleifera leaves against high fat diet-induced obesity in rats. Advances in Biology. $2014 \mathrm{Jul}$ 10;2014.

17. Bidkar JS, Ghanwat DD, Bhujbal MD, Dama GY. Anti-hyperlipidemic activity of Cucumis melo fruit peel extracts in high cholesterol diet induced hyperlipidemia in rats. Journal of Complementary and Integrative Medicine. 2012 Sep 24;9(1).

18. Pande S, Srinivasan K. Potentiation of hypolipidemic and weight-reducing influence of dietary tender cluster bean (Cyamopsis tetragonoloba) when combined with capsaicin in high-fat-fed rats. Journal of agricultural and food chemistry. 2012 Aug 13;60(33):8155-62.

19. Ferreira EA, Gris EF, Rebello JM, Correia JF, de Oliveira LF, Wilhelm Filho D, et al., The 2', 4', 6'-trihydroxyacetophenone isolated from Myrcia multiflora has antiobesity and mixed hypolipidemic effects with the reduction of lipid intestinal absorption. Planta medica. 2011 Sep;77(14):1569-74.

20. Husain GM, Chatterjee SS, Singh PN, Kumar V. Hypolipidemic and antiobesity-like activity of standardised extract of Hypericum perforatum L. in rats. ISRN pharmacology. 2011 Apr 12;2011.

21. Milagro F I, Campión J, Martínez JA. Weight gain induced by high-fat feeding involves increased liver oxidative stress. Obesity. 2006 Jul 1;14(7):1118-23.

22. Murase $\mathrm{T}$, Mizuno $\mathrm{T}$, Omachi $\mathrm{T}$, Onizawa $\mathrm{K}$, Komine $\mathrm{Y}$, Kondo $\mathrm{H}$, et al., Dietary diacylglycerol suppresses high fat and high sucrose diet-induced body fat accumulation in C57BL/6J mice. Journal of Lipid Research. 2001 Mar 1;42(3):372-8.

23. Buettner R, Schölmerich J, Bollheimer LC. High-fat diets: modeling the metabolic disorders of human obesity in rodents. Obesity. $2007 \mathrm{Apr}$ $1 ; 15(4): 798-808$.
24. Sonne SB, Yadav R, Yin G, Dalgaard MD, Myrmel LS, Gupta R, et al., Obesity is associated with depot-specific alterations in adipocyte DNA methylation and gene expression. Adipocyte. 2017 May 5:1-0.

25. Irimia J M, Meyer C M, Segvich D M, Surendran S, DePaoli-Roach A A, Morral $\mathrm{N}$ et al., Lack of liver glycogen causes hepatic insulin resistance and Steatosis in mice. Journal of Biological Chemistry. 2017 May 8:jbc-M117.

26. Ji Q. Treatment Strategy for Type 2 Diabetes with Obesity: Focus on Glucagon-Like Peptide-1 Receptor Agonists. Clinical Therapeutics. 2017 May 16.

27. West DB, York B. Dietary fat, genetic predisposition, and obesity: lessons from animal models. The American journal of clinical nutrition. 1998 Mar 1;67(3):505S-12S

28. Lee JJ, Lee HJ, Oh SW. Antiobesity Effects of Sansa (Crataegi fructus) on 3T3-L1 Cells and on High-Fat-High-Cholesterol Diet-Induced Obese Rats. Journal of medicinal food. 2017 Jan 1;20(1):19-29.

29. Velasquez MT, Bhathena SJ. Role of dietary soy protein in obesity. International journal of medical sciences. 2007;4(2):72.

30. Wang J, Ke W, Bao R, Hu X, Chen F. Beneficial effects of ginger Zingiber officinale Roscoe on obesity and metabolic syndrome: a review. Annals of the New York Academy of Sciences. 2017 May 15.

31. Caraballo SC, Comhair TM, Dejong CH, Lamers WH, Koehler SE. Dietary treatment of fatty liver: High dietary protein content has an antisteatotic and antiobesogenic effect in mice. Biochimica et Biophysica Acta (BBA)Molecular Basis of Disease. 2017 Jul 31;1863(7):1789-804.

32. Ansell BJ, Navab M, Hama S, Kamranpour N, Fonarow G., Hough G., et al., Inflammatory/antiinflammatory properties of high-density lipoprotein distinguish patients from control subjects better than high-density lipoprotein cholesterol levels and are favorably affected by simvastatin treatment, Circulation 108(22) (2003) 2751-6.

33. Chang CJ., Tzeng TF, Liou SS, Chang YS, Liu IM, Kaempferol regulates the lipid-profile in high-fat diet-fed rats through an increase in hepatic PPARalpha levels, Planta medica 77(17) (2011) 1876-82.

34. Mancini FP, Lanni A, Sabatino L, Moreno M, Giannino A, Contaldo F., et al., Fenofibrate prevents and reduces body weight gain and adiposity in dietinduced obese rats, FEBS letters 491(1-2) (2001) 154-8.

35. Manubhai CH, Rasiklal MD, Natvarlal BS, Kishorbhai VV, Rajkishor TC, Lipidlowering activity of Cow urine ark in guinea pigs fed with a high cholesterol diet, Avicenna journal of phytomedicine 4(5) (2014) 354-63.

\section{PICTORIAL ABSTRACT}

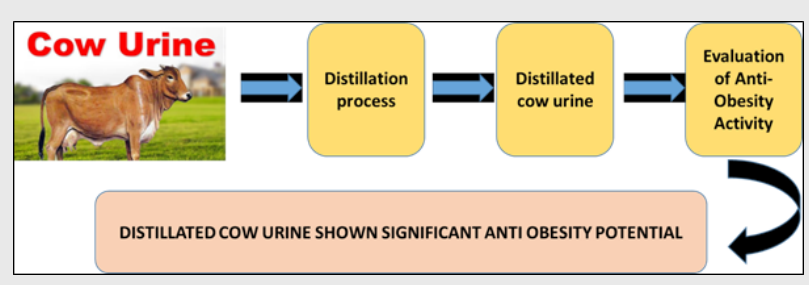

\section{SUMMARY}

Obesity has established significant attention as a major health impediments. In present scenario the management of obesity is a big challenge which reinforces the research to find out a new, suitable, safe and economical therapy. Traditionally, cow urine has been used for the management of many diseases and disorders. In this study cow urine and its distillate used for assememt of Anti-obesity potential. The parameters have been estimated in High fat diet induced obese Wistar rats such as BMI, abdominal circumference, obesity index, atherogenic index, lipid profile along with histological evaluation of white adipose tissues. The results of present research, have successfully proved that cow urine and its distillate can cure obesity. Thus, it can be concluded that the cow urine and its distillate have anti-obesity potential, which supports its traditional claim. Further, studies will be carried out to determine the Bio active fraction of cow urine and its distillate along with probable mechanism of action. 


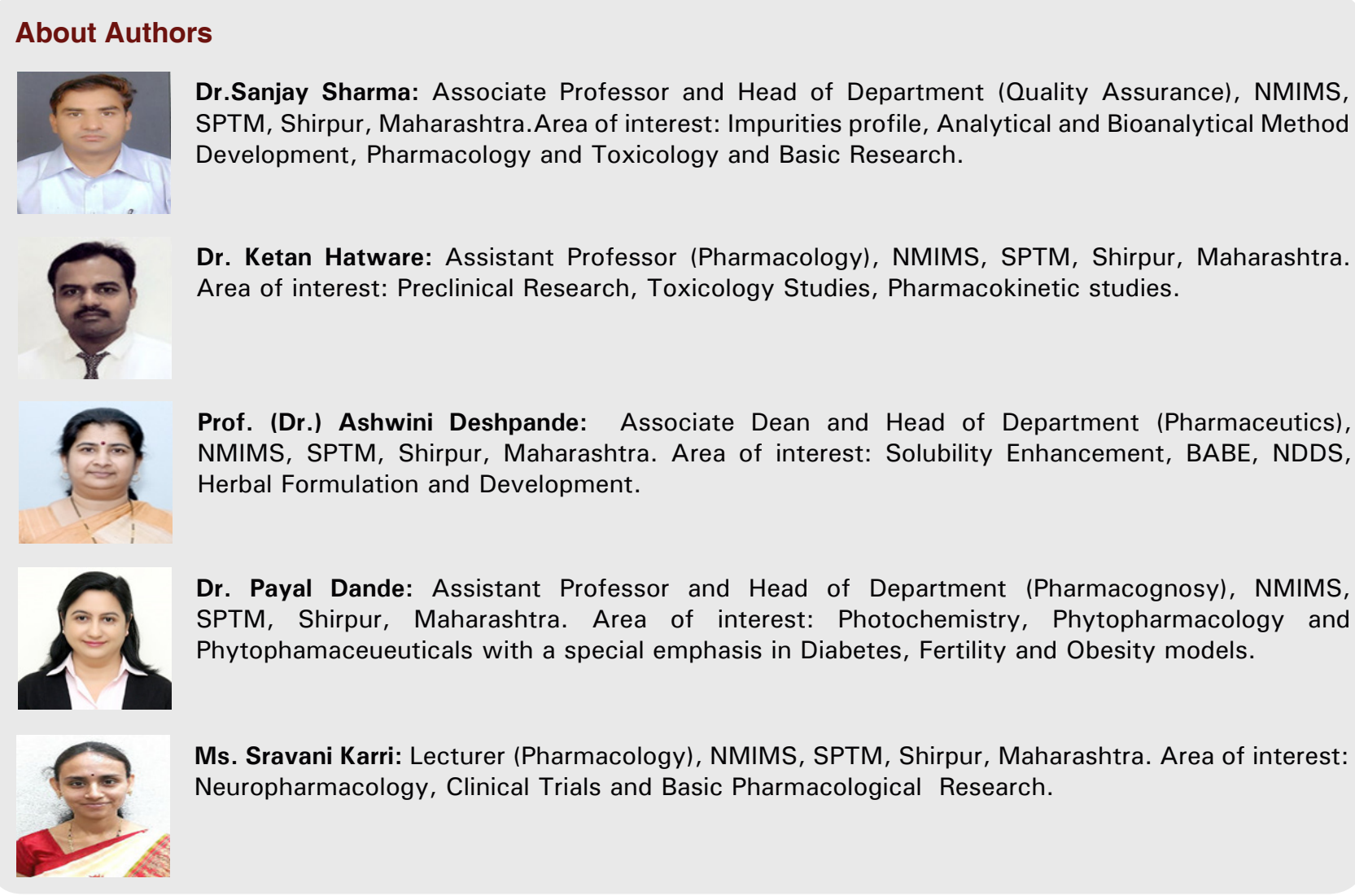

Cite this article: Sharma S, Hatware K, Deshpande A, Dande P, Karri S. Antiobesity Potential of Fresh Cow Urine and its Distillate - A Biomedicine for Tomorrow. Indian J of Pharmaceutical Education and Research. 2017;51(4S):S712-S21. 